\title{
INTRACAPSULAR AND PARA-ARTICULAR CHONDROMA OF KNEE: CASE REPORTS
}

\author{
Temelkovski Zlatko, ${ }^{1}$ Nanceva Jasminka, ${ }^{1}$ Samardziski Milan, \\ Nancheva Andrea, ${ }^{2}$ Andonovski Alan ${ }^{1}$ \\ ${ }^{1}$ University Clinic for Orthopaedic Surgery, Skopje, Macedonia \\ ${ }^{2}$ General Hospital "8mi Septemvri”, Skopje, Macedonia
}

Primljen/Received 10. 01. 2017. god.

Abstract: Introduction: Intracapsular and $\mathrm{Pa}-$ ra-articular chondroma is a rare variant of the extraskeletal chondromas. It arises from the capsule and/or the para-articular connective tissue of the large joints (mostly the knee) and is a result of cartilaginous metaplasia. In the course of time these tumors ossify and this is where their second name comes from: Para-articular osteochondromas. Case reports: We report six new cases of para-articular chondroma of the knee. On physical examination there was slow-growing solid mass in the knee and moderate pain. The radiological findings and CT scan show soft-tissue mass with variable amount of ossification, and on histological examination the presence of mature hyaline and connective cartilage was confirmed in all of the cases. Conclusion: The diagnosis of these benign tumors is made with correlation of clinical, radiological and histological features. Treatment of choice is surgical excision.

Key words: Para-articular, Chondroma, Osteochondroma, Knee.

\section{INTRODUCTION}

Extraskeletal chondromas are benign tumors which appear in three variants: synovial chondromatosis, para -articular chondroma and soft tissue chondroma. The first type is very common, but the last two variants are quite rare and they may show atypical features $(1,2,3)$.

The fibrous coat of the capsule of a joint and/or the para-articular connective tissue, very rare, can suffer cartilaginous metaplasia. As an end result of this metaplasia, intracapsular or para-articular chondromas are formed. In time, they usually ossify so they are also known as capsular and para- articular osteochondromas. Mostly seen in the large joints (the knee), they vary in si-
Prihvaćen/Accepted 27. 02. 2017. god.

ze depending on the size of the joint $(4,5,6,7)$. We have found only 30 cases of para-articular chondromas in the reviewed literature $(3,5,6)$. We report six new cases of capsular and para-articular chondroma of the knee with their clinical, radiological and histological features in the University Clinic for Orthopedic Surgery, Skopje, Macedonia in period 2007-2015.

\section{CASE REPORTS}

\section{Case report 1}

Male patient, 24 years old, reports with painful mass on the medial side of the right knee, with no record of trauma. He first noticed it one year prior to the examination. On physical examination the tumorous formation is movable, tender on palpation, produces pain during active motion. The profile $\mathrm{X}$-ray shows para- and supra-patellar soft tissue tumorous formation (Figure 1A). On CT- scan this soft tissue mass is clearly seen, oval shaped and intracapsular (Figure 1B). The tumor was surgically excised. During the operation, the intracapsular but extrasynovial position of the tu-

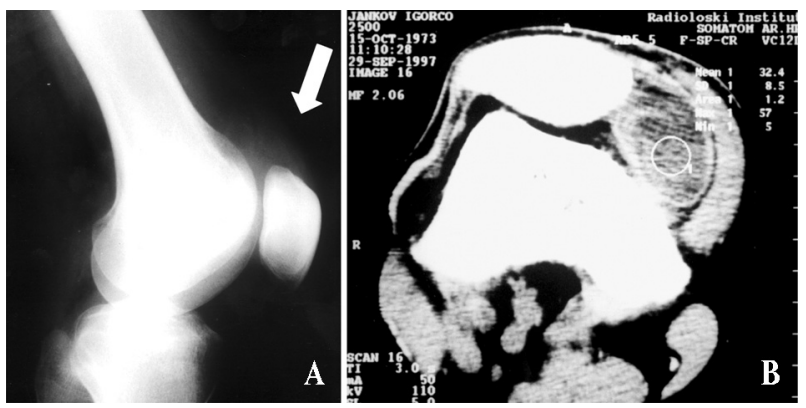

Figure 1. A. Lateral radiograph of the right knee: the arrow points to a parapatellar soft tissue mass $\boldsymbol{B}$. CT scan of the same knee: parapatelar, intracapsular soft tissue mass which has displased the patella 

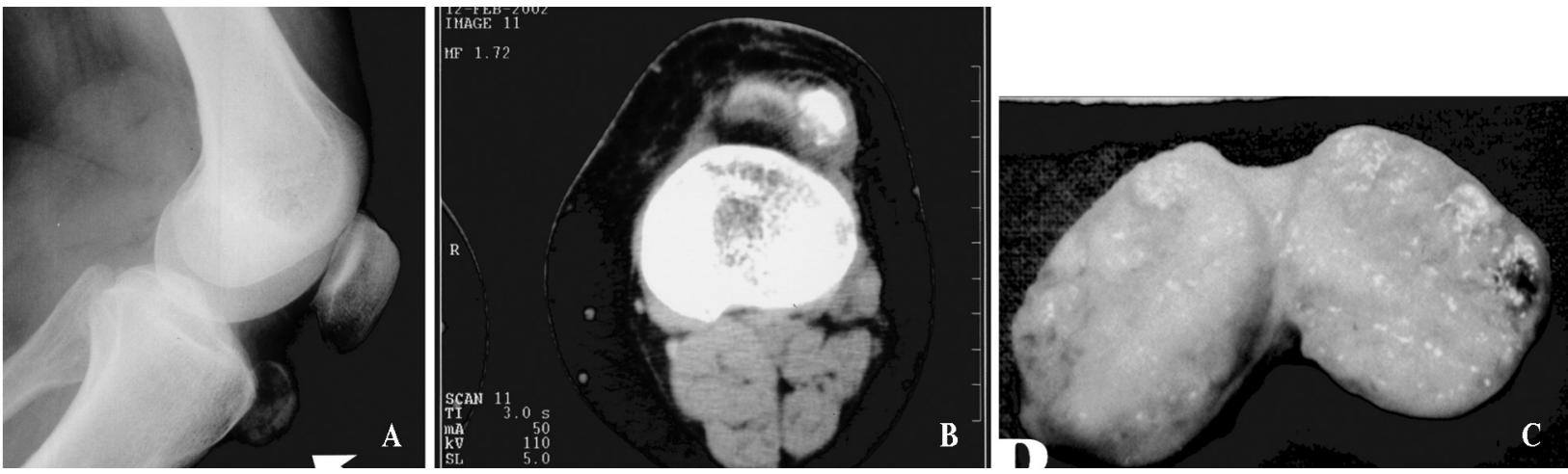

Figure 2. A. Lateral radiograph of the right knee: large infrapatellar ossified mass. B. CT scan of the same knee: encapsulated ossified mass. C. Macroscopic appereance of the excised tumour on cross-section.

mor was confirmed. It was oval shaped, 8 × $5 \times 2.5 \mathrm{~cm}$. The histological examination showed mature hyaline cartilage with foci of mixomatous tissue with benign characteristics. The diagnosis was intracapsular chondroma without ossification.

\section{Case report 2}

Female patient, age 41 complains on a solid mass on the lateral aspect of the left knee that has been slowly growing for the past two years. It caused limitation of joint movement and required surgical removal. The lateral radiograph of the left knee showed infrapatellar ossified mass (Figure 2A), whilst the CT- scan showed mostly ossified, encapsulated tumor just beneath the lateral border of the patella, but not attached to it (Figure 2B). The surgically excised mass was oval, 3 x $3.5 \times 2.5 \mathrm{~cm}$ (Figure 2C), situated in the continuity with the capsule of the joint, but extrasynovial. Macroscopically, on cross section there is a central zone of mature trabecular bone, surrounded by a hyaline cartilage cup (Figure 2C). On histological examination there was mature trabecular bone surrounded by hyaline cartilage with endochondral ossification. The diagnosis was intracapsular chondroma with high rate of ossification.

\section{Case report 3}

A female patient aged 72 was admitted after a mild trauma of the left knee. Physical exam showed painful mass under the patella and limited flexion and extension of the knee which were present for more than 10 years. The recent trauma of the left knee caused pain and swelling of the knee. The lateral radiograph of the knee showed subpatellar, partly ossified mass and the transverse section on CT-Scan showed posttraumatic hematoma in the knee joint, as well as soft tissue tumor with ossification beneath the patella, situated in the para-articular connective tissue (Figure 3.A and B). The
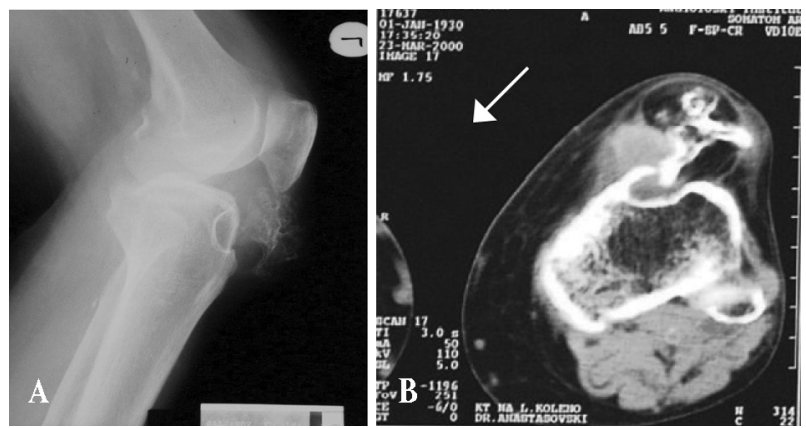

Figure 3. A. Lateral X-ray of the knee shows the localization of the chondroma. B. Transverse section on computer tomography of the knee shows proximal tibia, chondroma and posttraumatic hematoma (arrow)

diagnosis was para-articular chondroma of the knee with ossification.

\section{Case report 4}

Female patient aged 56 complained on the intense pain and lack of extension in her right knee. There was no history of trauma, but she could remember heavy activities after which progressive restriction of the extension and pain started. History of the patient showed that she had slightly painful, slowly growing lump seated beneath and laterally of the patella for more than 30
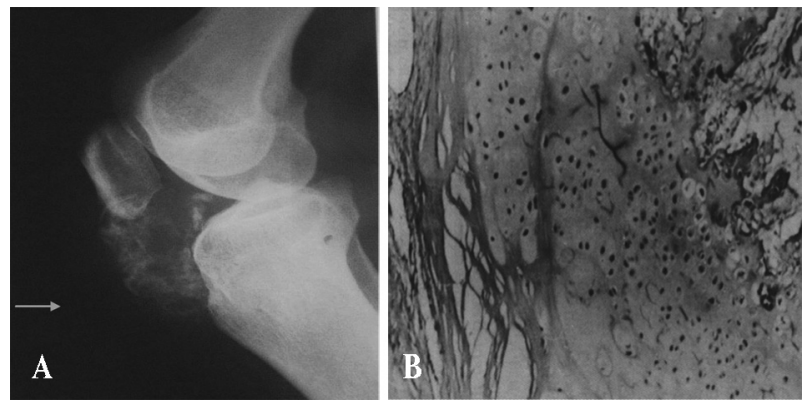

Figure 4. A. Lateral x-ray of the right knee, showing infrapatellar chondroma (arrow) B. histopathology of the chondroma (HE x600) 
years (Figure 4A and B). After the surgical extirpation of the para-articular chondroma, full range of painless motion was regained.

\section{Case report 5}

Female patient aged 62 with long history of pain. Anterior knee pain, swelling of the joint, loss of function (flexion and full extension) (Figure 5A and B, Figure $6 \mathrm{~A}$ and $\mathrm{B}$ ).
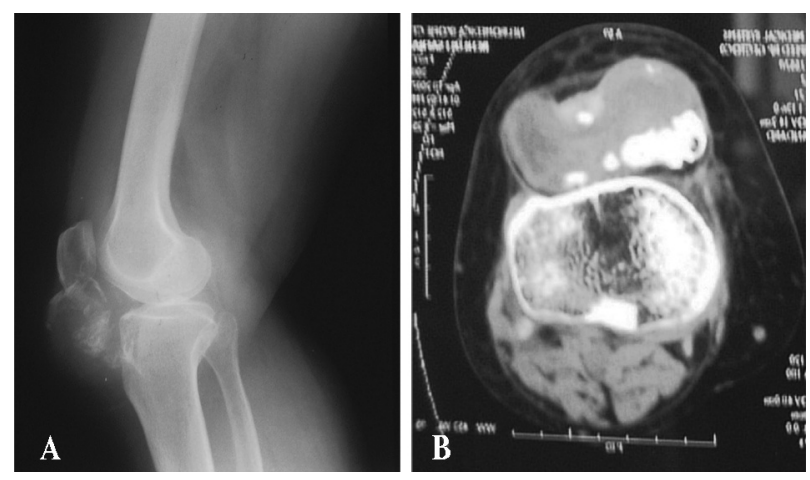

Figure 5. A. Lateral x-ray of the right knee, showing large infrapatellar chondroma $\boldsymbol{B}$. Size and position of the chondroma
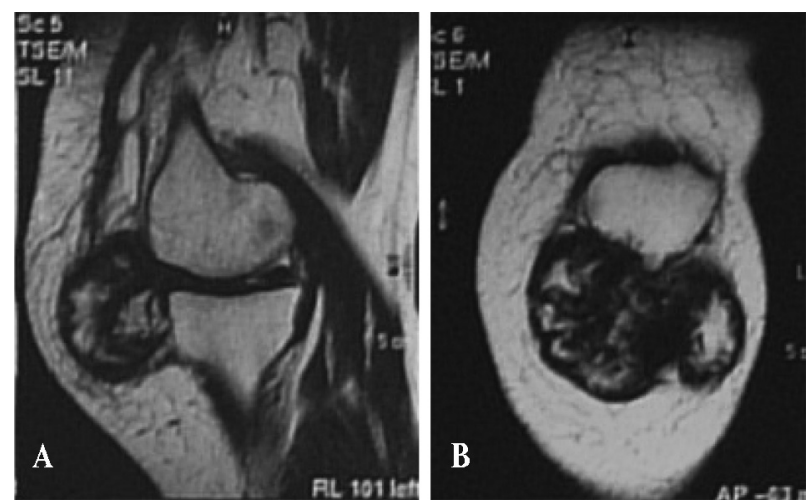

Figure 6. A. MRI investigation - lateral view, big tumor in anterior part of the knee and compression of the cartilage of knee condyles. B. Correlation with patella, the tumor volume displaced the patella and make pressure in his inferior part

\section{Case report 6}

Female patient aged 53 with local discomfort of the right knee, long history of pain, swelling, painful function and feeling of free body in his knee joint. Clinically moving tissue in his joint, pseudo blockage in her knee joint (Figure 7, 8).

\section{DISCUSSION AND CONCLUSION}

Para-articular and intracapsular chondromas are rare benign tumors mostly seen in the vicinity of the

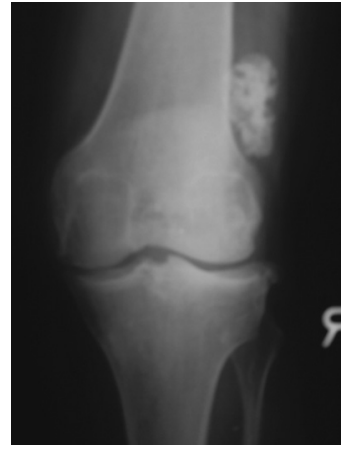

Figure 7. Large Chondroma in the lateral recessus of the Knee

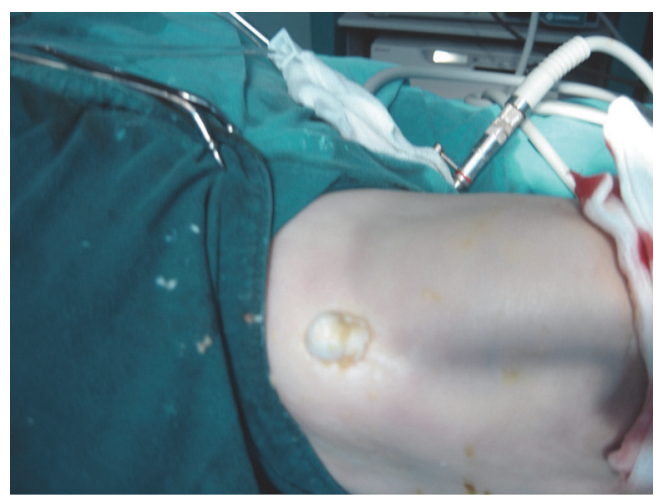

Figure 8. Arthroscopic procedure in tumor extirpation

large joints. They were often named capsular osteoma, osteochondroma or chondroma depending on the proportion of bone and cartilage (8). According to Jaffe, there is only one single lesion in question regardless of the ossification, and in 1958 he classified all these terms under one entity: intracapsular and para-articular chondroma (5). The Pathogenesis of these tumors is also controversial. They most likely originate from the connective tissue in the vicinity of the capsule of a joint or from the outer coat of the capsule as a result of cartilaginous metaplasia. Prior trauma is unlikely to play any significant role in the pathogenesis of these tumors. In the beginning comprising exclusively of cartilaginous tissue, in the course of time they usually ossify $(3,4)$. That is why their "second name" used in the literature comes from osteochondroma.

From the relatively small number of reported cases we can conclude that, although there have been cases in the ankle, elbow and the hip joint $(3,9)$, they are mostly seen in the knee joint $(4,6,8)$. The location is para-articular and intracapsular, mostly infrapatellar or medial to the patella. The reported age varies from 12 to 75 years. The clinical complaints are of some month to several years of local discomfort, moderate pain, slow growing mass and some degree of limited motion in the joint. Radiologically, there is a soft tissue mass with a different degree of central radiodensity due to 

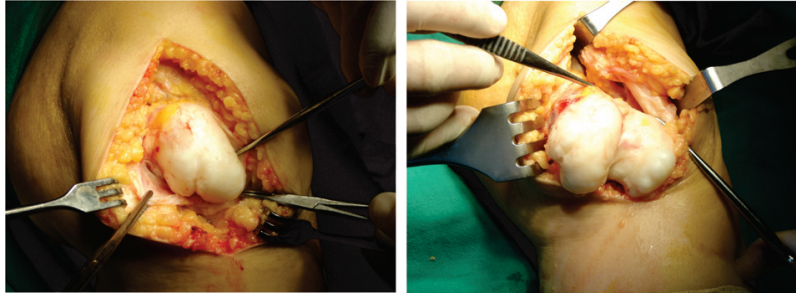

Figure 9. Operative procedure in case 5

ossification. Macroscopically their size varies, depending on the size of the involved joint, from 2 to $10 \mathrm{~cm}$ (Figure 9).

The six cases we report have all the features of the previously reported chondroma found in the literature. Clinically they present with moderate pain and restricted range of motion in the involved knee joint. On plain radiographs, there was a soft tissue mass with a different degree of ossification while the CT- scan has enabled us to make a more detailed analysis as to the exact position of the tumor (intracapsular or extracapsular) (8), its relationship with the adjacent structures, it's size and structure (7). In all of our cases, the tumors were intracapsular, but with no direct contact with the joint. Grossly, they were large, and the pathological analysis confirmed the presence of hyaline cartilage with varia- ble amounts of mature trabecular bone $(10,11)$. Using the definition of Jaffe, the diagnosis in all of the six cases was: para-articular chondroma. The treatment in all of the cases was surgical excision.

The diagnosis of these benign tumors is made with clinical and radiological correlation with the pathological features $(8,9)$. Although rarely seen, they should be considered in the differential diagnosis of soft tissue masses around the joints: hematoma, bursitis, periosteal chondroma, synovial sarcoma, and synovial chondrosarcoma. The treatment of choice for these tumors is surgical excision, while being careful not to injure the joint integrity. Malignant transformation has never been reported. With correct diagnosis unnecessary aggressive surgical treatment will be avoided.

\section{Conflict of interest}

The authors declare that there is no conflict of interest.

\section{Licensing}

This work is licensed under a Creative Commons Attribution 4.0 International (CC BY 4.0) Licence

\title{
Sažetak
}

\author{
INTRAKAPSULARNI I PARAARTIKULARNI HONDROMI \\ KOLENA: PRIKAZI SLUČAJA \\ Temelkovski Zlatko, ${ }^{1}$ Nanceva Jasminka, ${ }^{1}$ Samardziski Milan, ${ }^{1}$ \\ Nancheva Andrea, Andonovski Alan ${ }^{1}$ \\ ${ }^{1}$ University Clinic for Orthopaedic Surgery, Skopje, Macedonia \\ ${ }^{2}$ General Hospital "8mi Septemvri", Skopje, Macedonia
}

Uvod: Intrakapsularni i paraartikularni hondromi su retke varijante ekstraskeletalnih hondroma. Nastaju od kapsule i/ili paraartikularnog vezivnog tkiva velikih zglobova (najčešće kolena) i rezultat su kartilaginozne metaplazije. Tokom vremena ovi tumori osifikuju i otuda proističe njihov drugi naziv: paraartikularni osteohondromi.

Prikazi slučaja: Prikazujemo 6 novih slučajeva paraartikularnih hondroma kolena. Na fizikalnom pre-

\section{REFERENCES}

1. Chung EB, Enzinger FM. Chondroma of soft parts. Cancer. 1978; 41(4): 1414-24.

2. Hagan RF, Schoneker PL. Para-articular osteochondroma. Am J Orthop. 1995; 24(1): 65-7.

3. Gayle EL, Morrison WB, Carino JA, Parsons TW, Liang CY, Stevenson A. Extrasceletal osteochondroma of the foot. Skeletal Radiol. 1999; 28(10): 594-8. gledu uočava se spororastuća, tvrda masa u kolenu i bol umerenog intenziteta. Radiološki nalazi i CT pokazuju mekotkivnu promenu sa varijabilnim procentom osifikacije, a na histološkom pregledu primećuje se prisustvo zrele hijaline hrskavice, kao i vezivne hrskavice u svih 6 slučaja.

Zaključak: Dijagnoza ovih benignih tumora je postavljena u korelaciji sa kliničkom slikom, radiološkim i histološkim promenama. Lečenje je hirurška ekscizija.

4. Gonzales Lois C, Garcia de la Torre JP, Santos Briz Terron A, Vila J, Manrique Chico J, Martinez Tello FJ. Intracapsular and para-articular chondroma adjacent to large joints: report of three cases and review of the literature. Skeletal Radiol. 2001; 30(12): 672-6.

5. Jaffe HL. Intracapsular and Para-articular Chondroma. In: Henry L. Jaffe: Tumors and Tumorous Conditions of the Bones and Joints. Philadelphia: Lea \& Febiger, 1958: $567-9$. 
6. Reith JD, Bauer TW, Joyce MJ. Para-articular osteochondromas of the knee: report of two cases and review of the literature, Clin Orthop. 1997; 334: 225-32.

7. Singh R, Jain M, Siwach R, Rohilla S, Sen R, Kaur K. Large para-articular osteochondroma of the knee joint: a case report. Acta Orthop Traumatol Turc. 2012; 46 (2): 139-43.

8. Džoleva-Tolevska R, Poposka A, Georgieva D, Božinovski Z, Nanceva J, Gjoshev S. Comparative analyses of diagnostic methods in knee injuries. Sanamed. 2016; 11(1): 39-45.
9. Steiner GC, Meushar N, Norman A, Present D. Intracapsular and para-articular chondromas. Clin Orthop. 1994; 303: 231-6.

10. Sakai H, Tamai K, Iwamoto A, Saotome K. Para-articular chondroma and osteochondroma of the infrapatellar fat pad: a report of three cases. Int Orthop. 1999; 23(2): 114-7.

11. Dhanda S, Quek ST, Bathla G, Jagmohan t.Intra-articular and Peri-articular Tumors and umour mimics- what a clinician and onco-imaging radiologist should know. Malays J Med Sci. 2014; 21(2): 4-19.

\section{Correspondence to / Autor za korespondenciju}

Zlatko Temelkovski, MD, Ph.D

Clinic for Orthopaedic Surgery, Vodnjanska 17, 1000 Skopje, Macedonia.

Tel.: ++38970245 818, fax: ++389023165137

E-mail: ztemelkovski2002@yahoo.com 